\title{
The mouse waved-2 phenotype results from a point mutation in the EGF receptor tyrosine kinase
}

\author{
Noreen C. Luetteke, ${ }^{1}$ Harmony K. Phillips, ${ }^{1}$ Ting H. Qiu, ${ }^{1}$ Neal G. Copeland, ${ }^{4}$ H. Shelton Earp, ${ }^{1,2}$ \\ Nancy A. Jenkins, ${ }^{4}$ and David C. Lee ${ }^{1,3,5}$ \\ ${ }^{1}$ Lineberger Comprehensive Cancer Center, and Departments of ${ }^{2}$ Pharmacology, and ${ }^{3}$ Microbiology and Immunology, \\ University of North Carolina School of Medicine, Chapel Hill, North Carolina 27599-7295 USA; ${ }^{4}$ Mammalian Genetics \\ Laboratory, ABL-Basic Research Program, Frederick Cancer Research and Development Center, Frederick, Maryland \\ 21701-1201 USA
}

\begin{abstract}
Mice harboring the waved-1 (wa-1) and waved-2 (wa-2) mutations exhibit skin and eye abnormalities that are strikingly similar to those of TGF- $\alpha$-deficient mice, and wa-1 and TGF- $\alpha$ were recently shown to be allelic. Because the wa-2 mutation was mapped previously to the vicinity of the EGF/TGF- $\alpha$ receptor (EGFR) gene on mouse chromosome 11, we hypothesized that the wa-2 phenotype might result from a defect in either the expression or activity of EGFR, or both. In the present report, we show that EGFR mRNA and protein of normal size are expressed in wa-2 liver and skin at levels that are comparable to those in the corresponding normal tissues, and that the ability of wa-2 EGFR to bind ligand is unaltered. However, ligand-dependent autophosphorylation of wa-2 EGFR is diminished 5- to 10-fold in vitro, and the ability of wa-2 EGFR to phosphorylate an exogenous substrate is reduced by $>90 \%$ compared with that of the control receptor. EGF-induced tyrosine phosphorylation, including that of EGFR itself, is also diminished in skin, particularly at lower doses of exogenous EGF. To establish the nature of the wa-2 mutation, we determined the nucleotide sequence of the coding region of normal and wa-2 murine EGFR cDNAs. A comparison of these sequences revealed a single-nucleotide transversion resulting in the substitution of a glycine for a conserved valine residue near the amino terminus of the tyrosine kinase domain. The importance of this mutation was confirmed by showing that its introduction into an otherwise normal EGFR markedly reduced the receptor's tyrosine kinase activity in transfected Chinese hamster ovary cells. Finally, in situ hybridization analysis demonstrated expression of EGFR predominantly in the outer root sheath of active hair follicles in neonatal mice. As we previously localized TGF- $\alpha$ mRNA to the inner root sheath, this pattern of EGFR expression is consistent with the effect of the wa-2 mutation on hair structure, and together with our previous characterization of TGF- $\alpha$-deficient mice, reveals a critical role for signaling by this ligand/receptor system in skin.
\end{abstract}

[Key Words: EGF receptor; mutation; tyrosine kinase; in situ; hair follicle]

Received October 12, 1993; revised version accepted January 6, 1994.

A range of cellular activities, including proliferation, migration, and differentiation, are controlled by signal transduction systems that are activated by the binding of polypeptide growth factors to cell-surface receptors. The majority of these receptors consist of an extracellular ligand-binding domain linked to a cytoplasmic sequence with intrinsic protein kinase activity that is specific for tyrosine residues (for review, see Ullrich and Schlessinger 1990; also see Carpenter and Wahl 1990). One of the better characterized tyrosine kinase receptors is the epidermal growth factor receptor (EGFR), a 170-kD integral membrane glycoprotein. The extracellular domain of EGFR includes two cysteine-rich regions. The intra-

${ }^{5}$ Corresponding author. cellular domain comprises a juxtamembrane region containing sites for threonine/serine phosphorylation that may be required for modulation of EGFR activity by other signaling systems, a tyrosine kinase domain homologous to that of other receptor and nonreceptor tyrosine kinases, and a carboxy-terminal region that contains regulatory sites for tyrosine autophosphorylation. EGFR binds, and is activated by, a family of polypeptide ligands that is named for the first discovered member, epidermal growth factor (EGF) (Cohen 1962). This expanding family includes transforming growth factor- $\alpha$ (TGF- $\alpha$ ) (Marquardt et al. 1984), amphiregulin (Shoyab et al. 1989), heparin-binding EGF (HB-EGF) (Higashiyama et al. 1991), and betacellulin (Sasada et al. 1993; Shing et al. 1993|, and the amphiregulin-related Schwannoma-de- 
rived growth factor (SDGF) may be yet another distinct member (Kimura et al. 1990). Binding of these various ligands to EGFR in cell culture typically leads to enhanced protein phosphorylation at tyrosine residues, activation of transport systems, and in some cell lines, stimulation of phosphoinositide turnover. These early responses are typically followed several hours later by increased synthesis of specific macromolecules (both RNA and protein), and within 12-48 hr, stimulation of DNA synthesis. Expression of EGFR is widespread, and in rodents, EGFR mRNA, or protein, are detected in most adult tissues with particularly high levels in liver. EGFR-binding activity is also present in certain fetal tissues (Adamson 1990; Wiley et al. 1992). Despite a wealth of cell culture data, physiological roles for the EGFR signaling system have not been well defined. Furthermore, little is known regarding possible distinctions between physiological responses evoked by different members of the EGF ligand family. To begin to address these issues, we recently used gene targeting in embryonic stem (ES) cells to derive a line of mice that is homozygous for a disrupted TGF- $\alpha$ gene and, hence, cannot express functional TGF- $\alpha$ protein (Luetteke et al. 1993). These mice are healthy and fertile but are distinguished by pronounced waviness of whiskers and fur. Individual coat hairs are bent and kinked, and contain regions of irregular septulation and caliber. These hairshaft defects are accompanied by aberrant curvature, disorientation, and misalignment of active hair follicles. Additionally, homozygous and, to a lesser extent, heterozygous TGF- $\alpha$ mice display eye anomalies of variable incidence and severity. The development of abnormal skin architecture, wavy hair, and eye problems in response to loss of TGF- $\alpha$ was simultaneously described by Mann et al. (1993), who used a different targeting strategy to inactivate the TGF- $\alpha$ gene.

A number of recessive mouse mutations affecting coat texture have been described previously (Trigg 1972; Lyon and Searle 1989). Two of these, waved-1 (wa-1) and waved-2 (wa-2), show hair and eye alterations that are strikingly similar to those of the TGF- $\alpha$-deficient mice (Crew 1933; Keeler 1935; Butler and Robertson 1953; Bennett and Gresham 1956; Trigg 1972). Because wa-1 and TGF- $\alpha$ map to a similar region on mouse chromosome 6 (Fowler et al. 1993; Barrow et al. 1994; N.G. Copeland and N.A. Jenkins, unpubl.|, the possibility that $w a-1$ and TGF- $\alpha$ are related was examined previously. Crosses between TGF- $\alpha$-targeted and wa-1 mice confirmed that the two loci are allelic (Luetteke et al. 1993; Mann et al. 1993|, and expression of a normal-sized TGF- $\alpha$ mRNA was shown to be significantly reduced in several tissues relative to that in control mice (Luetteke et al. 1993). Because we localized TGF- $\alpha$ transcripts to the hair follicles of normal mice, these various results confirm a critical role for this particular EGFR ligand in skin. On the other hand, wa-2, a cell autonomous mutation (McLaren and Bowman 1969), maps to the vicinity of the EGFR gene on mouse chromosome 11 (Lyon and Searle 1989). Hence, we sought to determine whether the wa-2 phenotype might result from a defect in either the expression or activity of EGFR. In the present report, we show that the wa-2 EGFR contains a point mutation within its tyrosine kinase domain that greatly diminishes its activity in vitro and leads to reduced EGF-dependent tyrosine phosphorylation in skin, particularly at lower doses of exogenous EGF. Together with our demonstrations that EGFR and TGF- $\alpha$ transcripts are localized to the outer and inner root sheaths, respectively, these findings define a physiological context in which interaction between EGFR and one of its ligands is critical. Our results also indicate that a mutation in a signaling protein, in this case EGFR, can have consequences that are tissue specific.

\section{Results \\ EGFR transcripts are localized to the outer root sheath of hair follicles}

To further investigate the role of TGF- $\alpha$ /EGFR interactions in hair follicle function and morphology, we performed in situ hybridization analyses of sections of normal backskin and snout in the active hair growth phase (anagen). An antisense RNA, corresponding to the intracellular ligand-binding domain of mouse EGFR, specifically detected prominent expression of EGFR transcripts in the outer root sheath of both vibrissal (Fig. la, arrowheads) and pelage (Fig. 1d, arrow) hair follicles of mice at 7 days of age. This pattern of expression, which was similarly observed with an antisense probe derived from cDNA sequences encoding the extracellular domain of the receptor, is distinguished from that of TGF- $\alpha$ transcripts, as they were primarily localized to the adjoining inner root sheath (Fig. lb, arrowheads; see also Luetteke et al. 1993). These data confirm that ligand and receptor are positioned appropriately to regulate interactions between inner and outer root sheaths that are thought to be important for hair growth (Straile 1962; Hardy 1992). Interestingly, EGFR transcripts were observed along the entire length of the outer root sheath from the proliferative bulb to the basal epidermis (Fig. 1d; data not shown), whereas TGF- $\alpha$ transcripts were confined longitudinally to a limited region of inner root sheath above the bulb (Luetteke et al. 1993). This could be consistent with differential expression of other EGFR ligands. Finally, we note that while Nanney et al. (1992) immunolocalized EGFR and PLC- $\gamma 1$ primarily to the basal layer of normal skin, they did not examine expression of these proteins in active hair follicles.

\section{Expression of EGFR is unaltered in wa-2 mice}

To determine whether the wa-2 phenotype results from reduced expression of either EGFR mRNA or protein, we performed Northern and Western blot analyses. As shown in Figure 2A, normal-sized EGFR transcripts of $\sim 9.6,6.5,5.0$, and $2.7 \mathrm{~kb}$ were expressed in livers of adult wa-2 homozygotes and heterozygotes at levels comparable to those in adult $\mathrm{B} 6 \mathrm{C} 3$ mice. Whereas only the 6.5and 5.0-kb mRNAs were detected in neonatal skin, these 

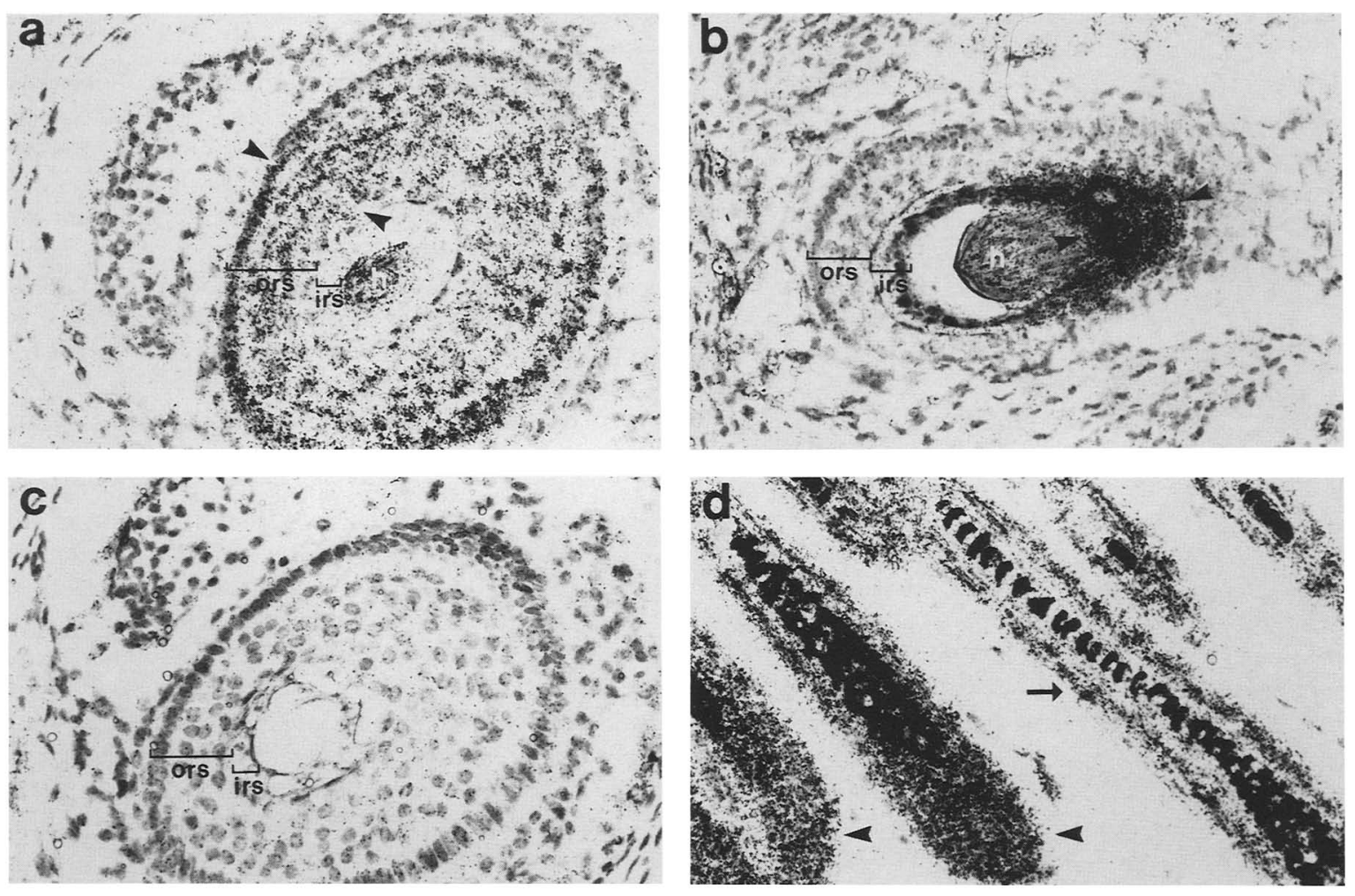

Figure 1. In situ hybridization detection of EGFR and TGF- $\alpha$ transcripts in normal hair follicles. (a) Cross section of a whisker follicle in the snout of a 7-day-old pup hybridized to an antisense cRNA probe corresponding to the extracellular domain of mouse EGFR. Specific hybridization (arrowheads) is prominent in the outer root sheath. (b) Comparable section hybridized to an antisense cRNA probe for mouse TGF- $\alpha$. Hybridization is most intense next to one side of the vibrissal hairshaft, in the inner root sheath. $(c)$ Snout section adjacent to that in a, hybridized to the sense cRNA of the mouse EGFR cDNA. (d) Hybridization of the antisense EGFR cRNA to a section of backskin from a 7-day-old mouse showing expression in the hair bulbs (arrowheads), as well as in the outer root sheath along the hairshaft (arrow). All magnifications are $400 \times$. (ors) Outer root sheath; (irs) inner root sheath; (h) hairshaft.

were also expressed at similar levels in wa-2 homozygous and wa-2 heterozygous mice. Moreover, comparable levels of EGFR protein were detected by an anti-rat EGFR antibody in microsomal and plasma membrane fractions prepared from livers of control and wa-2 mice, and the wa-2 EGFR migrated with an apparent size (170 $\mathrm{kD}$ ) identical to that of the normal protein (Fig. 2B). These results distinguish the basis of the wa-2 phenotype from that of wa-1, which results from reduced expression of TGF- $\alpha$ mRNA and protein (Luetteke et al. 1993|, and they also indicate that wa-2 EGFR does not contain significant sequence deletions.

\section{The tyrosine kinase of the wa-2 EGFR shows diminished activity in vitro}

To examine its functional competency, we compared the autophosphorylation of normal and wa-2 EGFRs in liver membranes in response to increasing amounts of EGF. As expected, we observed a ligand-dependent increase in ${ }^{32} \mathrm{P}$ incorporation into the $170-\mathrm{kD}$ EGFR protein in control liver membranes (Fig. 3A). Because this radiolabeling was resistant to alkali treatment, it is presumed to represent tyrosine autophosphorylation of the receptor. In contrast, EGF-dependent phosphorylation of the wa-2 EGFR from homozygous liver membranes was markedly reduced even at the highest dose of EGF (Fig. 3A), and TGF- $\alpha$-induced autophosphorylation of the wa-2 EGFR was also markedly decreased (data not shown). Because the preceding autophosphorylation experiments were performed at $0^{\circ} \mathrm{C}$, we considered the possibility that the wa-2 defect might be temperature sensitive. However, autophosphorylations carried out at $37^{\circ} \mathrm{C}$ showed an even greater difference between the activities of the control and wa-2 receptors (Fig. $3 \mathrm{~A}$ ), although autophosphorylation of both receptor forms was essentially ligandindependent at this higher temperature. Densitometric analyses of the autoradiographs shown in Figure 3 revealed autophosphorylation of the $w a-2$ EGFR at $0^{\circ} \mathrm{C}$ to be reduced five- and sixfold compared with the control receptor at 600 and $2000 \mathrm{ng} / \mathrm{ml}$ of EGF, respectively. In contrast, the comparative reductions at $37^{\circ} \mathrm{C}$ were 16 and 25-fold, respectively. Finally, we note the intense phosphorylation of a polypeptide of $\sim 42 \mathrm{kD}$ that was observed only with control membranes incubated at $37^{\circ} \mathrm{C}$ (Fig. 3A). Though it is similar in size to mitogenactivated protein kinase (MAP kinase) (Campos-Gonzalez and Glenney 1992), the $42-\mathrm{kD}$ protein was not rec- 
A

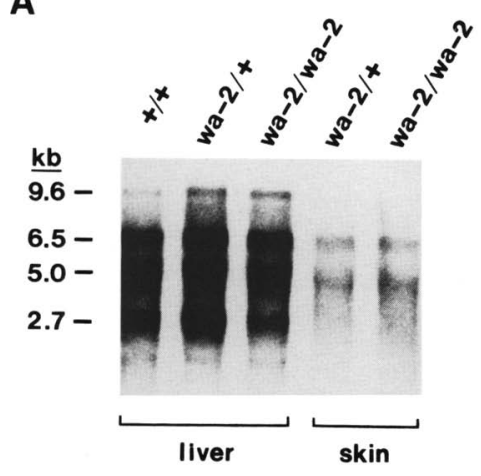

B

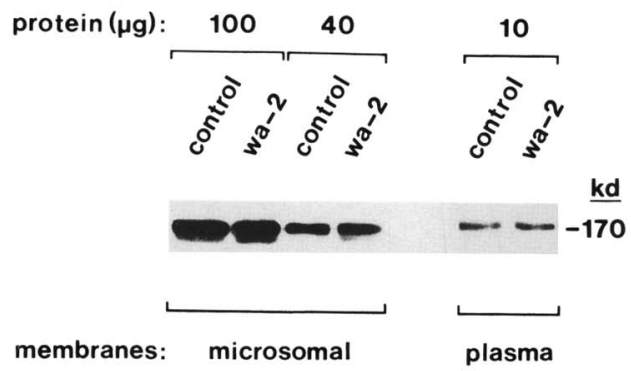

Figure 2. Expression of EGFR mRNA and protein in normal and wa-2 mice. $(A)$ Northern blot of total RNAs $(15 \mu \mathrm{g})$ isolated from the livers of adult male $\mathrm{B} 6 \mathrm{C} 3(+/+)$ and age-matched $w a-2$ heterozygous $(w a-2 /+)$ and homozygous (wa-2/wa-2) mice, and from the backskin of 10-day-old heterozygous and homozygous wa-2 littermates. Blots were probed with nicktranslated, full-length murine EGFR cDNA. (B) Western blot of proteins from microsomal and plasma membranes isolated from the livers of adult normal and wa-2 homozygous mice, probed with rabbit antiserum directed against the carboxy-terminal region of rat EGFR.

ognized by an anti-MAP-kinase antibody (data not shown) and its identity is presently unknown.

EGFR has been shown previously to be activated in the absence of ligand by solvents, detergents, and antibodies (Rubin and Earp 1983; Schreiber et al. 1983; Yarden and Schlessinger 1987). As shown in Figure 3B, treatment of nonsolubilized membranes with dimethylsulfoxide (DMSO), or solubilized membranes with antiserum directed against the EGFR extracellular domain, induced a concentration-dependent autophosphorylation of the receptor in control, but not wa-2, samples. These results imply that the wa-2 defect is not merely the result of impaired binding of ligand to the wa-2 receptor. Measurements of ${ }^{125}$ I-labeled EGF binding to hepatic microsomal membranes from wa-2 mice showed it to be similar to that observed with B6C3 membranes. The competition binding curves shown in Figure 4 fit a single site model with apparent dissociation constants estimated at 0.55 and $1.05 \mathrm{nM}$ for normal and wa-2 EGFR, respectively. These are similar to the previously reported value of $0.67 \mathrm{~nm}$ for rat liver membranes (Friedenberg et al. 1986).

To assess the activity of the wa-2 EGFR tyrosine kinase toward exogenous substrates, we examined its ability to phosphorylate synthetic peptide polymers containing tyrosine (Zick et al. 1985). This particular assay was chosen, as phosphorylation of these polymers is limited to tyrosine residues and is independent of $s r c$ homology 2 (SH2) domain binding, which could be compromised with an underphosphorylated mutant EGFR. Equivalent amounts of protein were immunoprecipitated from solubilized wa-2 homozygous or control wild-type microsomal membranes with an antisera (1382) against the extracellular domain of rat EGFR. As shown in Figure $3 \mathrm{~B}$, binding of this antibody activates the receptor, and in other experiments we found that pretreatment with EGF did not enhance the level of receptor kinase activity over that observed in response to antibody binding alone /data not shown). Immunoprecipitates were incubated with $\left[\gamma^{-32} \mathrm{P}\right] \mathrm{ATP}$ and poly-glutamic acid (poly-Glu), poly-glutamate/tyrosine (4:1) (poly-Glu/Tyr), or poly-glutamate/ alanine/tyrosine (poly-Glu/Ala/Tyr) as substrates. As shown in Figure 5, normal EGFR catalyzed a 95- and 147 -fold increase in the incorporation of ${ }^{32} \mathrm{P}$ into poly$\mathrm{Glu} / \mathrm{Tyr}$ and poly-Glu/Ala/Tyr, respectively, relative to poly-Glu. In contrast, the corresponding increase produced by the wa-2 EGFR was less than threefold, and was only slightly above that obtained with the preimmune precipitates from both genotypes. SDS-PAGE of the phosphorylated polymers revealed an intense smear of ${ }^{32} \mathrm{P}$ incorporation only in the case of poly-Glu/Tyr incubated with the control EGFR. Taken together, these results confirm that tyrosine phosphorylation of both the wa-2 EGFR itself, as well as of exogenous substrates, is greatly reduced in vitro.

\section{wa-2 EGFR activity is also impaired in vivo}

Administration of EGF to newborn mice has been shown to rapidly induce tyrosine phosphorylation of EGFR and other proteins in multiple tissues (Donaldson and Cohen 1992). Hence, we used this approach to examine the activity of the wa-2 EGFR tyrosine kinase in vivo. For these analyses, we used 1-week-old pups because the wa-2 phenotype is most evident during anagen of the first hair cycle. Because we were unable to distinguish (either by phenotype or genotype) heterozygous and wild-type pups, we mated wa-2 homozygous males to $w a-2$ heterozygous females to generate equal numbers of $w a-2$ homozygous and heterozygous (control) littermates. At 1 week of age, homozygous mutant and heterozygous control littermates were injected subcutaneously with either PBS alone or PBS containing a pharmacological dose of EGF $(10 \mu \mathrm{g} / \mathrm{g}$ body weight $)$. Ten minutes later, the pups were sacrificed, and liver, skin, and kidney homogenized in a buffer containing detergent and protease and phosphatase inhibitors. Equivalent amounts of tissue protein were then resolved by SDSPAGE, and immunoblots probed with either anti-phosphotyrosine antibody (PY-20) or anti-rat EGFR antise- 
A

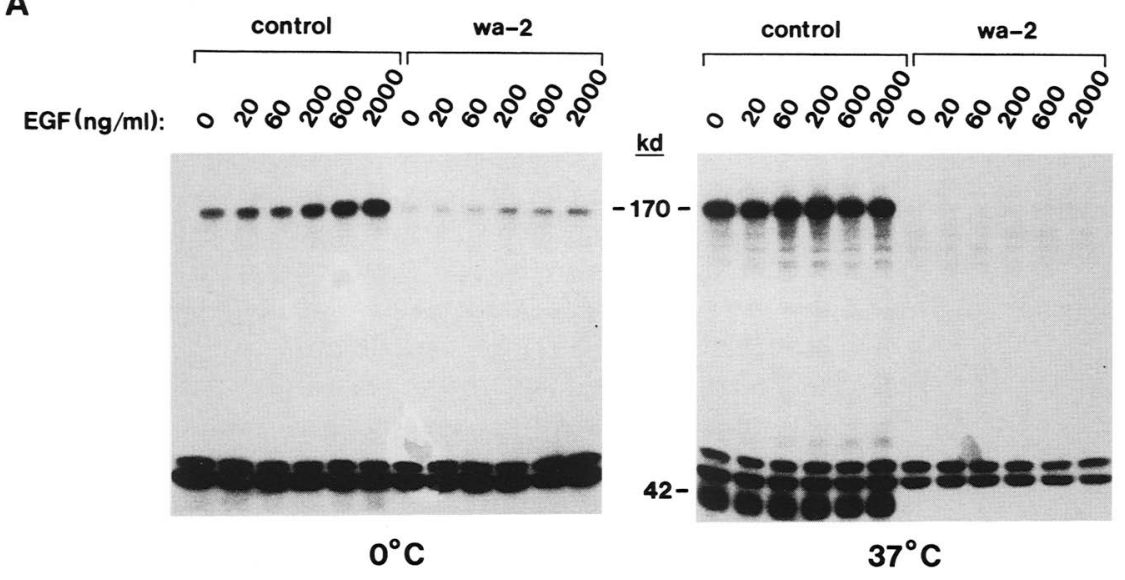

Figure 3. Autophosphorylation of the EGFR in control and wa-2 liver membranes. $(A)$ Dose response of protein $(50$ $\mu \mathrm{g}$ ) from control $(+1+)$ or wa-2 $(-1-)$ liver membranes to EGF $(0-2000 \mathrm{ng} / \mathrm{ml})$, with $\left[\gamma^{32} \mathrm{P}\right] \mathrm{ATP}$ incubations at $0^{\circ} \mathrm{C}$ (left) or $37^{\circ} \mathrm{C}$ (right). Prior to autoradiography, SDS-PAGE gels were treated with $1 \mathrm{M}$ $\mathrm{KOH}$ for $2 \mathrm{hr}$ at $55^{\circ} \mathrm{C}$ to preferentially remove serine and threonine phosphorylation. (B) Ligand-independent autophosphorylation of normal and wa-2 EGFR. Mem-

B
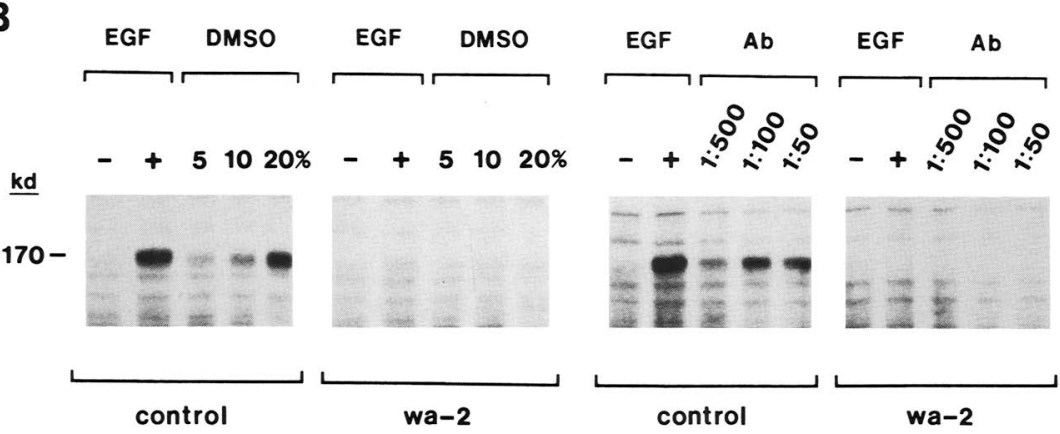

branes $(50 \mu \mathrm{g})$ were preincubated for $1 \mathrm{hr}$ on ice with or without EGF $(2 \mu \mathrm{g} / \mathrm{ml})$, or with increasing concentrations of DMSO, and phosphorylation initiated with $\left[\gamma^{-32} \mathrm{P}\right]$ ATP. Alternatively, membrane samples were first solubilized in $1 \%$ Triton X-100 on ice, then diluted and incubated for $1 \mathrm{hr}$ at room temperature in the absence or presence of EGF, or in several dilutions of antiserum against the extracellular domain of the EGFR prior to the phosphorylation reaction at $0^{\circ} \mathrm{C}$. rum. As reported previously for normal mice (Donaldson and Cohen 1992), injection of EGF in the heterozygous controls led to enhanced tyrosine phosphorylation of both EGFR and a protein of $\sim 55 \mathrm{kD}$ in liver, skin, and kidney (Fig. 6A). Tyrosine phosphorylation of 120- and $35-\mathrm{kD}$ species was also increased, particularly in skin and kidney. Surprisingly, tyrosine phosphorylation of these same proteins (including EGFR itself) was significantly stimulated in corresponding tissues from wa-2 homozygous pups, though phosphorylation of both EGFR and p120 was consistently (albeit slightly) reduced in skin (Fig. 6A).

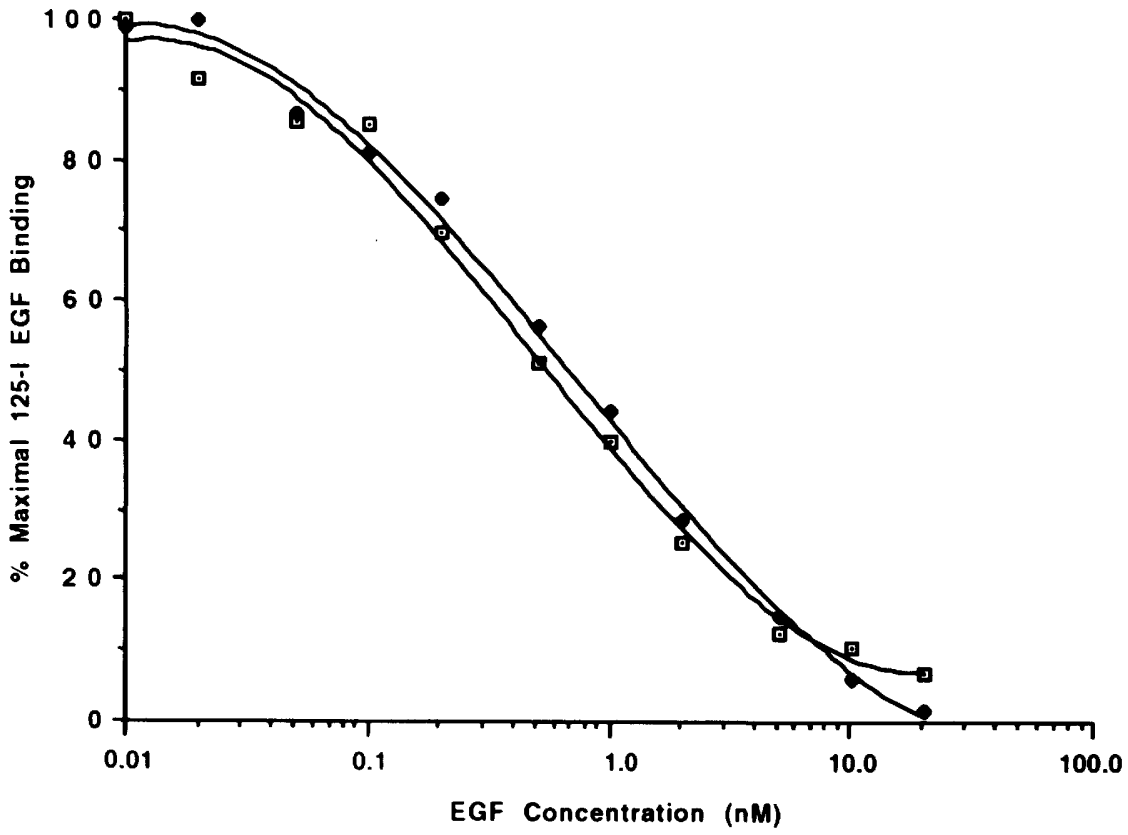

Figure 4. Comparison of EGF binding in control $(+1+)$ and $w a-2(-1-)$ liver mem. branes. Membrane suspensions $(40 \mu \mathrm{g}$ protein in $200 \mu \mathrm{ll}$ ) were incubated for $4 \mathrm{hr}$ at $4^{\circ} \mathrm{C}$ with $0.5 \mathrm{nM}{ }^{125}$ I-labeled EGF and EGF $(0-20 \mathrm{nM})$, and bound ligand recovered by vacuum filtration and washing. Data points were derived from the mean of three values, with standard errors within $10 \%$ of the mean. (Open symbols) controls; (closed symbols| wa-2. Nonspecific binding, measured in the presence of $2 \mu \mathrm{M}$ EGF, was $<10 \%$ of total binding. Maximal specific binding was $2237 \mathrm{cpm}$ for control and 2838 cpm for wa-2 samples. 


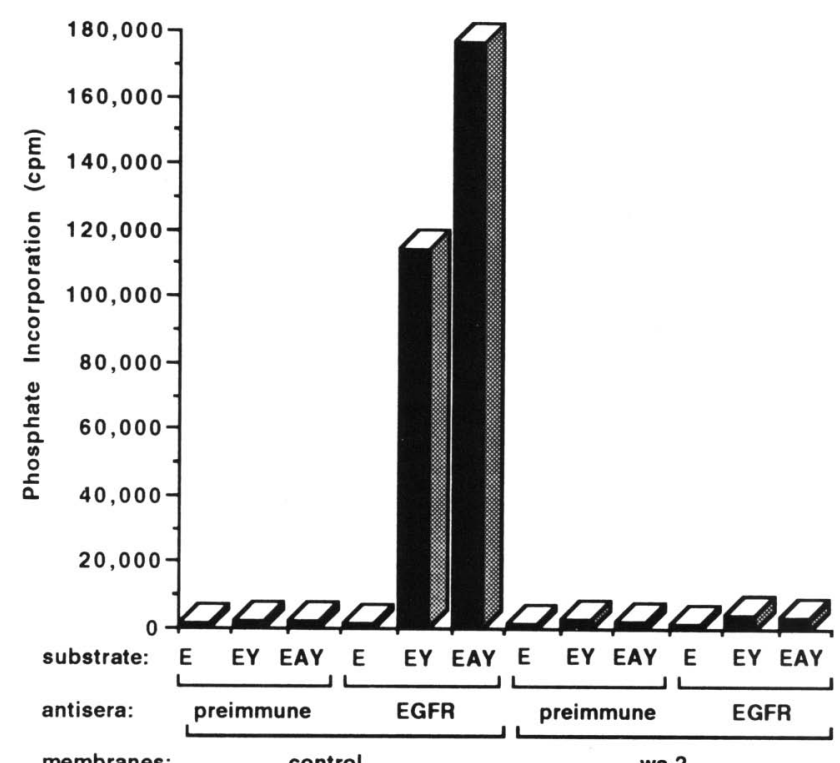

membranes:

control

tissues were not attributable to differential receptor content, as Western blots of the same homogenates probed with anti-rat EGFR antibody confirmed comparable levels of receptor protein (Figure 6A-C, bottom). Finally, note that (as described above) to compare age-matched littermates of known genotypes, these studies were carried out with wa-2 heterozygotes as controls. Hence, the difference between tyrosine phosphorylation mediated by the normal and wa-2 EGFRs in vivo is potentially underestimated by these experiments.

To further evaluate the physiological significance of the reduced EGFR kinase activity in vivo, we injected one litter of 10 newborn mice daily for 2 weeks with 1 $\mu \mathrm{g} / \mathrm{g}$ of EGF (Cohen 1962; Tam 1985). Compared with PBS injection ( $n=2$ pups of each genotype), EGF similarly accelerated eyelid opening and incisor eruption by 2-3 days in both heterozygous ( $n=3$ pups) and homozygous $(n=3$ pups) wa-2 littermates. Interestingly, the administration of EGF to wa-2 homozygous mice did not override the wavy hair phenotype.

Figure 5. Tyrosine kinase assay of control $(+/+)$ and wa-2 $(-/-)$ EGFR. Liver microsomal membranes $(400 \mu \mathrm{g}$ protein per reaction) were solubilized and immunoprecipitated with preimmune rabbit serum or antiserum recognizing the EGFR extracellular domain. Washed immune complexes were then incubated for $15 \mathrm{~min}$ at $25^{\circ} \mathrm{C}$ with $5.0 \mu \mathrm{Ci}\left[\gamma^{-32} \mathrm{P}\right] \mathrm{ATP}$ and $2 \mathrm{mg} / \mathrm{ml}$ of either poly-Glu (E) or poly-Glu/Tyr (EY) or poly-Glu/Ala/ Tyr) (EAY). Reactions were centrifuged to pellet the immune complexes and eliminate the background contribution of EGFR autophosphorylation. Aliquots of the supernatant were spotted onto filter papers that were washed extensively and subjected to Cherenkov counting. Bars, mean values from triplicate assays, with standard errors within $10 \%$ of the mean.

Because the latter experiment was performed with a particularly high dose of EGF, it was repeated with lower doses of EGF (ranging from 0.25 to $2 \mu \mathrm{g} / \mathrm{g}$ body weight). As shown in Figure 6B, phosphorylation of EGFR, as well as of $\mathrm{p} 120$ and p55, was dose dependent in skin from both control and wa-2 homozygous mice, but a comparison of individual doses showed the levels of tyrosine phosphorylation to be consistently lower in wa-2 homozygous tissues versus control heterozygous tissues. Although they were also observed in liver (data not shown), differences between the activities of the control and wa-2 EGFRs were most evident in skin at doses of EGF that were minimally sufficient to yield significant phosphorylation relative to background levels (e.g., $1 \mu \mathrm{g} / \mathrm{g}$ body weight). Densitometric analysis of the results shown in Fig. 6B revealed an approximately sevenfold decrease in tyrosine phosphorylation of the pl 20 substrate in wa-2 homozygous versus control homogenates at a dose of 1 $\mu \mathrm{g} / \mathrm{g}$ EGF. Because other phosphoproteins migrated in the vicinity of EGFR, its phosphorylation was examined further by immunoprecipitation with EGFR antiserum prior to immunoblotting (Fig. $6 \mathrm{C}$ ). Compared with control, EGFR phosphorylation induced by $1 \mu \mathrm{g} / \mathrm{g}$ of EGF was reduced about fourfold in wa-2 homozygous skin. The differences in tyrosine phosphorylation in the $w a-2$

The wa-2 EGFR is mutated within the tyrosine kinase domain

Collectively, the previous findings are consistent with a mutation in the wa-2 EGFR-coding region. To identify the mutation, overlapping cDNAs corresponding to the extracellular domain and the transmembrane/cytoplasmic regions were generated by reverse transcription and polymerase chain reaction (RT-PCR) amplification of total RNAs from the livers of normal B6C3 and wa-2 homozygous mice. Resulting cDNAs were cloned and their nucleotide sequences determined by automated dideoxy sequencing. Discrepancies between the various clones were then investigated further by manual sequencing of selected regions. A total of four clones (two each, wildtype and $w a-2)$ corresponding to the extracellular domain were sequenced in the forward direction. The complete sequences of eight clones (four each, wild-type and $w a-2)$ corresponding to the transmembrane/cytoplasmic domain were determined. For each genotype, half of the latter clones were sequenced in the forward direction and half in the reverse direction. In a comparison of the individual sequences corresponding to the extracellular domain, only three different discrepancies were noted, and each appeared in only one of four clones examined. Similarly, a comparison of the eight transmembrane/cytoplasmic domain clones revealed a total of 10 different discrepancies, none of which appeared in more than one clone. These various discrepancies /most of which were silent/ were therefore judged to be PCR-generated artifacts.

The complete consensus nucleotide sequence and predicted amino acid sequence of the normal murine EGFR cDNA is presented in Figure 7A. Relative to human EGFR, the mouse protein contains a 2 amino-acid-insert immediately preceding the transmembrane domain and lacks 2 amino acids in the carboxy-terminal region. Thus, its overall length ( 1186 amino acids) is identical to that of the human receptor. The amino acid sequence of 
A

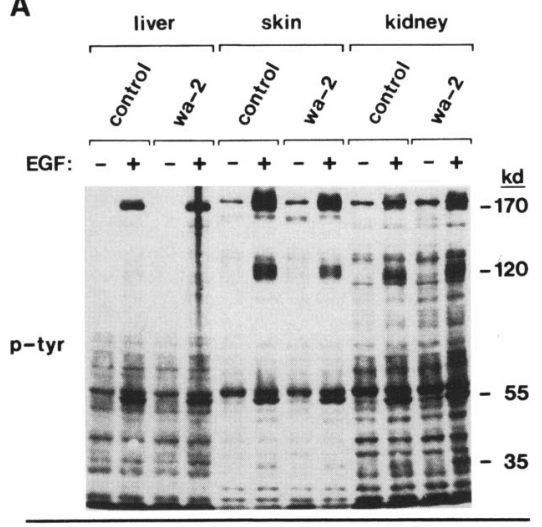

EGFR $=0-00000-170$
Figure 6. EGF-induced tyrosine phosphorylation in vivo. (A) Tyrosine phosphorylation in neonatal tissues expressing EGFR. One-week-old wa-2 heterozygous control and homozygous mutant littermates were administered PBS $(-)$ or EGF in PBS $1+1$ at $10 \mu \mathrm{g} / \mathrm{g}$ of body weight. Ten minutes later, pups were sacrificed and indicated tissues removed and homogenized in buffer containing 1\% Triton X-100 and protease and phosphatase inhibitors. Equivalent samples (200 $\mu \mathrm{g}$ protein) were subjected to SDS-PAGE and Western blotting with anti-phosphotyrosine antibody (top) or EGFR antiserum (bottom). (B) EGF dose response in skin. Experiment performed as in $A$, but with lower doses of EGF as indicated. $(C)$ EGFR autophosphorylation in neonatal skin. Skin homogenates (500 $\mu \mathrm{g}$ protein) from the experiment in $B$ were immunoprecipitated with EGFR antiserum, and then subjected to parallel Western blotting with anti-phosphotyrosine antibody (top) or EGFR antiserum (bottom).

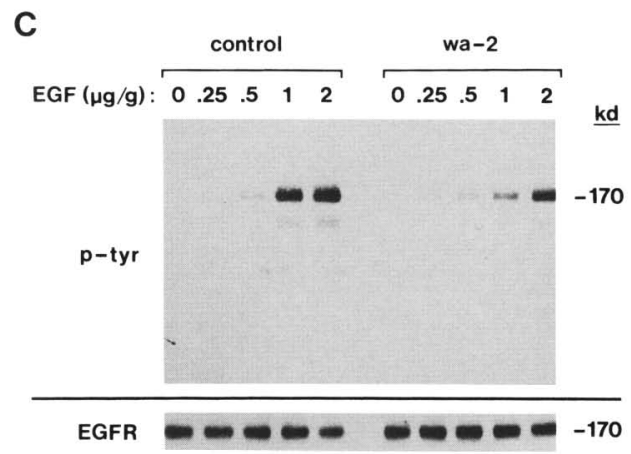

the extracellular portion predicted from this sequence is identical to that determined previously for EGFR from a different mouse strain (Avivi et al. 1991) and is $87 \%$ homologous with human EGFR. The cytoplasmic domain, which has not been reported previously for rodents, is $94 \%$ homologous with the human EGFR (Ullrich et al. 1984), with almost complete conservation of the tyrosine kinase domain as well as sites of tyrosine and serine/threonine phosphorylation. Overall, the mouse EGFR sequence is $95 \%$ homologous with that of rat receptor (T. Dawson and H.S. Earp, pers. comm.).

Significantly, comparison of the wa-2 EGFR cDNA sequence with the wild-type consensus sequence shown in Figure 7A revealed only a single consistent nucleotide difference involving the replacement of a thymidine with a guanosine (Figure $7 \mathrm{~B}$ ) in the tyrosine kinase domain. This transversion, which was observed with all four of the wa-2 clones, and not observed with any of the wild-type clones, would result in the substitution of a glycine for a valine (residue 743 ) in the third subdomain (as defined by Hanks et al. 1988) of the protein kinase sequence. Interestingly, this particular valine is conserved between human, mouse, and rat EGFRs, as well as in Her2/ErbB2/Neu (Table 1). Moreover, it is either conserved or conservatively replaced by an isoleucine or leucine in a multitude of receptor and nonreceptor tyrosine kinases (including the EGFR-related Her4/ErbB4; Plowman et al. 1993), as well as in a majority of known serine/threonine kinases (Hanks et al. 1988). Although it is replaced by alanine in the EGFR-related Her3/ErbB3, subdomain III of this latter protein shows little relatedness to the comparable region of other EGFR-related proteins and, in particular, lacks the glutamic acid residue that is otherwise conserved in both tyrosine and serine/ threonine protein kinases (see Table 1; Plowman et al. 1990).

\section{Introduction of the wa-2 mutation impairs normal receptor kinase activity}

The implicated valine residue at position 743 is encoded within a $768 \mathrm{bp}$ EcoRI fragment. This fragment is preserved in a full-length rat EGFR cDNA with $99 \%$ (254/ 256) conservation (relative to mouse) of the encoded amino acids. To confirm the importance of the wa- 2 valine 743 substitution, we replaced this portion of the rat EGFR cDNA with the corresponding EcoRI cassettes derived from wild-type and wa-2 mouse cDNAs. We chose this particular strategy because our PCR-generated mouse cDNAs could not be readily assembled into fulllength sequences, and most contained random mutations as described above. The two modified rat EGFR cDNAs were introduced separately into the plasmid pcDNA3 (Invitrogen) under the control of cytomegalovirus (CMV) promoter, and the presence of the appropriate mouse cassette (wild-type vs. wa-2) confirmed by nucleotide sequence analysis.

To assess the impact of the wa- 2 mutation, subconflu- 
Figure 7. Sequence comparison of normal and wa-2 murine EGFR cDNAs. Overlapping EGFR cDNAs were generated by reverse transcription and PCR amplification of total liver RNAs isolated from B6C3 $(+/+)$ and wa-2 $(-/-)$ mice, and subjected to automated dideoxy nucleotide sequence analysis. $(A)$ Deduced nucleotide and predicted amino acid sequence of the normal murine EGFR. Nucleotides are numbered from the first position of the initiating methionine, amino acids from the first residue following the predicted signal peptide. The transmembrane domain is underlined, arrowheads denote the boundaries of the tyrosine kinase domain homology as defined by Hanks et al. (1988), and the dot marks the position of a residue analogous to lysine 721 in the ATP-binding site of the human EGFR that is essential for tyrosine kinase activity. The amino acid substitution in the wa-2 EGFR is boxed, and the arrow points to the mutated nucleotide. Note that this sequence will appear in the EMBL, GenBank, and DDBJ nucleotide sequence data bases under accession number U03425. (B) A manual dideoxy sequencing gel comparing wild-type and wa-2 cDNAs in the region of the mutation (arrows). Asterisks indicate the predicted amino acid difference.

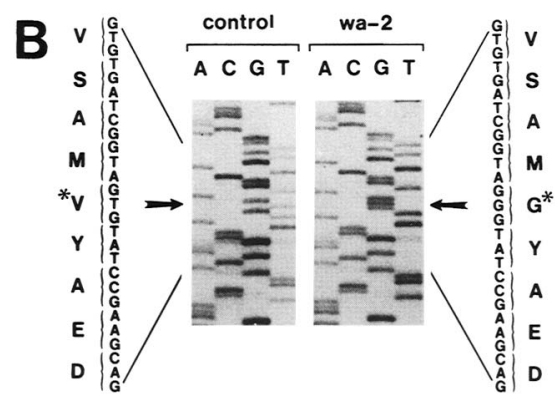


Table 1. Comparison of subdomain III sequences in various tyrosine kinases

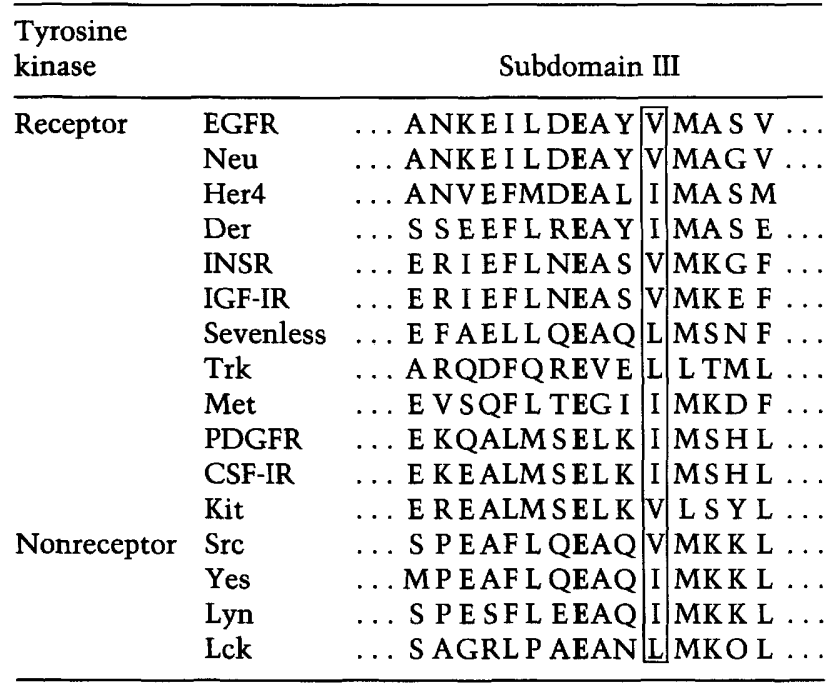

Subdomain III sequences from conserved tyrosine kinase domains are from Hanks et al. (1988). An invariant glutamic acid (E) residue is in boldface type; and the position of hydrophobic residues (valine- $\mathrm{V}$, isoleucine-I, leucine- $\mathrm{L}$ ) corresponding to the valine that is mutated in wa-2 mice is boxed. The subdomain III sequence shown for EGFR is completely conserved between the human, mouse, rat, and chicken species.

ent cultures (60-mm dishes) of the Chinese hamster ovary $(\mathrm{CHO})$ cell line were transiently transfected (lipofectamine; GIBCO/BRL) with $3 \mu \mathrm{g}$ of either the parental vector or constructs encoding the chimeric wild-type or $w a-2$ receptors. This particular cell line was chosen because it normally lacks detectable EGFR. Transfected cells were serum starved for $2 \mathrm{hr}$ and, $24 \mathrm{hr}$ after transfection, exposed to varying doses of exogenous EGF for 2 $\mathrm{min}$. Cells were then lysed, and equivalent amounts of protein immunoprecipitated with the rabbit anti-EGFR antibody. Resulting complexes were resolved on SDSPAGE and immunoblotted with anti-phosphotyrosine antibody. As shown in Figure 8, phosphotyrosine-centaining proteins of $\sim 170$ and $160 \mathrm{kD}$ were readily detected in samples from cells transfected with the wildtype EGFR construct but not the parental vector. Because both species were detected in parallel blots probed with anti-EGFR antibody (Fig. 8, bottom), we presume that the broad $170-\mathrm{kD}$ band corresponds to fully glycosylated EGFR, whereas the more defined $160-\mathrm{kD}$ species represents the biosynthetic precursor of the mature receptor, an intracellular form that contains core oligosaccharides added during or shortly after its translation (Soderquist and Carpenter 1984; Mayes and Waterfield 1984). This form acquires the ability to bind ligand prior to full maturation to the $170-\mathrm{kD}$ form /Slieker and Lane 1985). Note that consistent with this description, the phosphotyrosine content of the $170-\mathrm{kD}$ receptor is modestly enhanced in response to increasing concentrations of EGF, whereas that of the $160-\mathrm{kD}$ species is unchanged. In samples from cells transfected with EGFR containing the wa-2 mutation, on the other hand, only the $170-\mathrm{kD}$ phosphotyrosine-containing protein was observed. Whereas the phosphotyrosine content of this protein was more obviously enhanced in response to EGF, the absolute level of phosphotyrosine was markedly reduced at every EGF concentration relative to that of the wild-type receptor. Densitometric analysis of the $170-\mathrm{kD}$ EGFR in Figure 8 revealed the ratio of wild-type to $w a-2$ autophosphorylation to be $\sim 14-, 4-$, and 3-fold at EGF concentrations of 10,30 , and $100 \mathrm{ng} / \mathrm{ml}$, respectively. This difference in apparent phosphotyrosine content was not attributable to variations in the level of EGFR protein as shown by a parallel blot with anti-EGFR antibody (Fig. 8, bottom). Similar results were obtained in a separate experiment in which cells were transfected with $0.6 \mu \mathrm{g}$ of EGFR CDNAs, serum starved for $18 \mathrm{hr}$, and harvested at $48 \mathrm{hr}$ (data not shown). The discrepancy between the activation of the wild-type and wa-2 receptors was also observed following calcium phosphate transfection of $\mathrm{CHO}$ cells (data not shown). We interpret these collective results to indicate that the tyrosine kinase of the wild-type receptor is fully active and only marginally ligand-dependent because of a relatively high concentration of receptors in the transfected cells. This robust activity leads to ligand-independent transphosphorylation of the nascent, $160-\mathrm{kD}$ receptor in intracellular compartments. In contrast, the tyrosine kinase activity of receptor containing the wa-2 mutation is markedly impaired and is unable to self-activate in intracellular compartments even when overexpressed. However, the surface wa-2 receptor retains the ability to be partially stimulated by ligand.
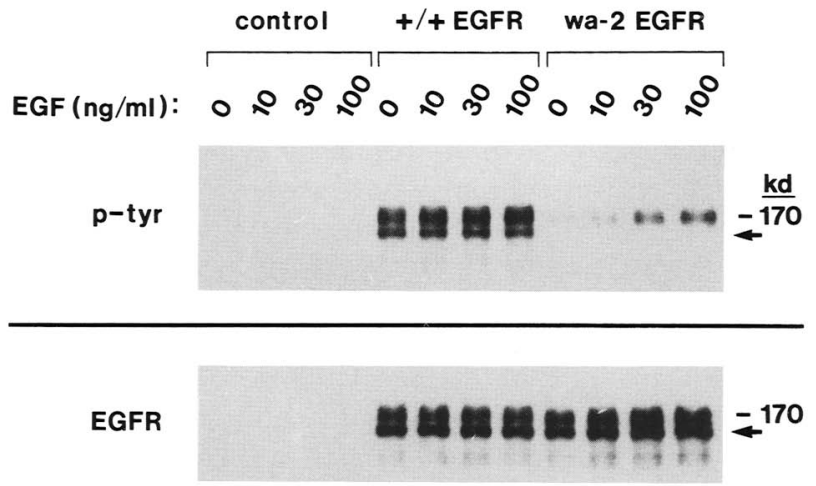

Figure 8. Comparison of wild-type and wa-2 EGFR activities in transfected cells. Subconfluent $(50-80 \%)$ CHO cells were lipofected with $3 \mu \mathrm{g}$ samples of parental pcDNA3 (control), or pcDNA3 containing wild-type $(+/+$ EGFR) or wa-2 EGFR cDNAs. At $22 \mathrm{hr}$ post-transfection, cells were serum starved for $2 \mathrm{hr}$ and then incubated with the indicated concentrations of EGF for 2 min. Cells were then lysed, and equivalent samples of protein $(500 \mu \mathrm{g})$ immunoprecipitated with a rabbit anti-EGFR antiserum (anti-ERCT). Immunoprecipitates were subjected to reducing SDS-PAGE and Western blotting with anti-phosphotyrosine antibody (top) or EGFR (bottom) antiserum. An arrow marks the position of the nascent, $160-\mathrm{kD}$ receptor. 


\section{Discussion}

In this report we have established the basis of the mouse wa-2 phenotype to be impaired tyrosine kinase activity of EGFR, and we have shown that this defect is the result of a mutation within the amino-terminal portion of the tyrosine kinase domain. Although the wa-2 mutation does not inactivate the tyrosine kinase, it does reduce its activity by $80-95 \%$ compared with that of control levels. The finding that such reductions are associated with skin and eye abnormalities (Keeler 1935; Butler and Robertson 1953) similar to those of mice containing disrupted TGF- $\alpha$ genes (Luetteke et al. 1993; Mann et al. 1993) confirms a requirement for signaling by this ligand/receptor pair in the normal development and functioning of these tissues. Our results point to one of the few examples in which a necessary interaction between a ligand and its receptor has been established. Another is provided by the corequirement for the steel factor and its receptor c-Kit, as mutations in either similarly produce mice with abnormalities in neural-crest derivatives, hematopoietic stem cells, and germ cells (Russell 1979).

EGFR transcripts and/or protein are detected, albeit in varying levels, in most tissues. Expression of the numerous EGF family ligands (EGF, TGF- $\alpha$, amphiregulin, HBEGF, and betacellulin) is also collectively widespread. It is perhaps surprising, therefore, that phenotypes associated with reduced EGFR signaling capacity are, as in the case of TGF- $\alpha$ deficiency, restricted to skin and (variably) eyes. With TGF- $\alpha$ deficiency, this limited phenotype was conjectured to be the result of functional redundancy, possibly reflecting the presence in other contexts of additional EGFR ligand family members. Although other EGFR-related proteins have been identified, including Her2/ErbB2/Neu (Bargmann et al. 1986), Her3/ErbB3 (Kraus et al. 1989; Plowman et al. 1990), and Her4/ErbB4 (Plowman et al. 1993), none of these related proteins have been shown to bind EGF family ligands. The latter observation suggests that if functional redundancy accounts for the restriction in phenotype in wa-2 mice, it must be accounted for by other ligand/receptor systems. Alternatively, because the wa-2 mutation does not completely inactivate the EGFR kinase, it is also possible that skin and eyes are particularly vulnerable to perturbations in the activity of this signaling system. We observed the level of EGF-induced phosphorylation in wa-2 mice to be most conspicuously and consistently reduced in skin (see Fig. 6B,C). Because the relevant EGFR activity (vis-a-vis the wa-2 defect) is presumably localized to hair follicles and, hence, represents only a portion of the activity assayed in skin homogenates, signaling in the affected compartment could be even more impaired relative to other tissues. Finally, consistent with an enhanced sensitivity of skin or hair follicles, it should also be noted that a number of distinct mutations have been shown to influence the texture of mouse fur (Trigg 1972; Lyon and Searle 1989).

The wa-2 defect provides the first example of a naturally occurring EGFR mutation. To our knowledge, va- line 743 (residue 741 in the human EGFR) has not been specifically and deliberately mutated, although deletion of amino acids immediately following it have been shown to inactivate the tyrosine kinase (Segatto et al. 1991). Additionally, a 10-amino-acid insertion just downstream of the ATP-binding domain of v-ErbB resulted in temperature-sensitive transforming and protein-tyrosine kinase activities ( $\mathrm{Ng}$ and Privalsky 1986). And, reminiscient of our own results, a 4-amino-acid insertion at residue 708 of the human protein abolished tyrosine kinase activity of the immunoprecipitated receptor but not its ability to stimulate ligand-dependent DNA synthesis (Prywes et al. 1986). Valine 743 is conserved in human, mouse and rat EGFRs, as well as in $\mathrm{Her} 2 / \mathrm{ErbB} 2 / \mathrm{Neu}$, and it is conservatively replaced by an isoleucine in Her4/ErbB4. It is also either conserved or conservatively replaced by leucine or isoleucine in a large number of both receptor and nonreceptor tyrosine kinases (Hanks et al. 1988; Table 1). The latter observation suggests that the placement of a hydrophobic amino acid at this relative position is critical, possibly because of its influence on local secondary and tertiary structures. That the substitution of a glycine at this position could have a detrimental effect is supported by the finding that the transforming potential of Ras can be activated as a result of the converse change, that is, the substitution of a valine for a glycine residue at position 12 of the Ras protein that is associated with a local, though critical, conformational change (Wittinghofer and Pai 1991). Additionally, the activity of chicken EGFR is stimulated by the deliberate replacement of an isoleucine for an invariant valine residue (position 702 in human EGFR) within the ATP-binding pocket (Shu et al. 1990|. How the glycine for valine substitution impairs the wa-2 EGFR kinase is presently unclear, though its proximity to lysine 723 (lysine 721 in human EGFR) raises the possibility that the mutation could exert its effect by compromising ATP binding.

Reduced tyrosine kinase activity could affect EGFR signaling through a number of distinct mechanisms. For example, cytoplasmic sequences have been implicated previously in the appearance of high, but not low, affinity EGF-binding sites on the cell surface, and some mutations that abolish tyrosine kinase activity (e.g., a 4-amino-acid insertion at residue 888 ) also prevented expression of the high affinity state (Prywes et al. 1986). However, it should be noted that we did not observe major differences in the apparent binding affinities of normal and wa-2 EGFRs. Another possibility is that the wa-2 mutation depresses receptor oligomerization that appears to be necessary for kinase activation (Schlessinger 1988). Alternatively, the wa-2 mutation could influence EGFR trafficking. Thus, certain tyrosine kinaseinactivating mutations, including the aforementioned residue 888 insertion (Prywes et al. 1986), also prevented EGFR down-regulation (Chen et al. 1987; Glenney et al. 1988), and the specific mutation of lysine 721 in the ATP-binding pocket altered cellular routing of EGFR such that internalized receptors were recycled to the cell surface (Honegger et al. 1987, 1990). Although mutations 
that effectively block EGFR down-regulation might generally be expected to enhance receptor signaling, the possibility exists that less drastic mutations (e.g., like that of $w a-2$ ) might influence EGFR routing in a manner that is detrimental to normal signaling, for example, by repressing a normal level of receptor recycling.

In addition to the preceding considerations, the wa-2 mutation could directly impact signaling pathways as a consequence of deficient tyrosine phosphorylation of the EGFR and physiologically relevant substrates. Kinetic analyses have demonstrated that EGFR autophosphorylation relieves a competitive inhibitory constraint on activity of the kinase toward exogenous substrates, perhaps through a conformational change (Bertics et al. 1985; Honegger et al. 1988). Furthermore, several key effector molecules in the mitogenic signal transduction pathway have been shown to preferentially associate with autophosphorylated receptor via interaction between their $\mathrm{SH} 2$ domains and the phosphotyrosines in the EGFR carboxyl terminus (Koch et al. 1991; Carpenter 1992). For example, receptor tyrosine kinase activity has been shown to be essential for its association with phospholipase C- $\gamma$ (PLC- $\gamma$ ) (Margolis et al. 1990), and efficient PLC- $\gamma$ phosphorylation is dependent on the presence of its SH2 domains (Rotin et al. 1992). In addition, GRB2, though apparently not a substrate of the EGFR tyrosine kinase, associates with phosphorylated receptors (Lowenstein et al. 1992) serving as an SH2 adaptor protein in a ternary complex with Son of sevenless (SOS) that stimulates ras activity (Buday and Downward 1993; Chardin et al. 1993; Egan et al. 1993; Gale et al. 1993; Li et al. 1993; Rozakis-Adcock et al. 1993). Another SH2 domaincontaining protein, $\mathrm{SHC}$, associates with and is phosphorylated by EGFR in cultured cells (Pelicci et al. 1992) and neonatal mouse tissues (Ruff-Jamison et al. 1993) exposed to EGF. Furthermore, SHC also associates with GRB2 (Rozakis-Adcock 1992). We detected a similar 55$\mathrm{kD}$ protein in our phosphotyrosine Western blots of neonatal mouse tissues, and the phosphorylation of this protein was depressed in wa-2 skin. Thus, the defective tyrosine kinase activity of the $w a-2$ receptor could impinge on several signaling pathways, possibly producing tissuespecific effects if association with key substrate(s) is preferentially perturbed in skin or hair follicles. Finally, it is interesting to note that the impact of the $w a-2 \mathrm{mu}-$ tation appeared greater when assayed in vitro than in vivo. Although the basis of this difference is presently unclear, it suggests that receptor phosphorylation or signal transduction is also modulated by extrinsic factors in addition to the receptor's own intrinsic tyrosine kinase activity. In this regard, it is interesting to note that a kinase-negative EGFR was shown recently to activate MAP kinase and undergo a low level of phosphorylation, possibly through an associated protein kinase activity (Campos-Gonzalez and Glenney 1992; Selva et al. 1993). Furthermore, cross talk between EGFR and other receptor signaling systems could dampen the effect of the wa-2 mutation in vivo (Kokai et al. 1988).

Numerous reports describe the sensitivity of skin and hair to exogenous EGFR ligands (Moore et al. 1983; Tam
1985; Barrandon and Green 1987; Vassar and Fuchs 1991). Our demonstration that EGFR transcripts are localized to the outer root sheath of hair follicles is consistent with a previous assay of receptor protein (Green et al. 1984; King et al. 1990|. Together with our recent findings (Luetteke et al. 1993), the present results further support the hypothesis that hair growth is, in part, controlled by interactions between EGFR and TGF- $\alpha$. The limited range of these interactions raises the possibility that they could be mediated by the membrane-bound TGF- $\alpha$ precursor (pro-TGF- $\alpha$ ) rather than soluble forms. Development of follicles and elongation of the hair shaft are believed to be dependent on coordinated proliferation and migration of the inner and outer root sheaths (Straile 1962; Hardy 1992). Disruptions in this coordinated function as a result of impaired EGFR signaling could produce hairs with irregular caliber and cell deposition (McLaren 1971). Finally, it is also possible that defective receptor signaling alters keratinization /Cheng et al. 1993) within the follicle or the shaft itself. Future studies should be aimed at understanding the role of EGFR signaling in this complex and dynamic system.

\section{Materials and methods}

\section{Animals}

Mice harboring the wa-2 mutation (B6C3-a/A-vt/vt-wa-2/wa2) and mice of the appropriate background strain (B6C3HF1) were obtained from The Jackson Laboratory (Bar Harbor, ME).

\section{Preparation of membranes}

The livers of adult males were Dounce homogenized in STE buffer [250 mM sucrose, $10 \mathrm{~mm}$ Tris- $\mathrm{HCl}(\mathrm{pH} 7.4), 2 \mathrm{~mm}$ EGTA] with protease inhibitors (1 mM PMSF, $20 \mu \mathrm{g} / \mathrm{ml}$ of leupeptin, 20 $\mu \mathrm{g} / \mathrm{ml}$ of aprotinin) and the homogenates centrifuged at $10,000 \mathrm{~g}$ for $30 \mathrm{~min}$. To collect microsomal membranes, supernatants were centrifuged at $100,000 \mathrm{~g}$ for $1 \mathrm{hr}$, and pellets resuspended in $1 \mathrm{ml}$ of $10 \mathrm{~mm}$ Tris- $\mathrm{HCl}(\mathrm{pH} 7.4), 0.15 \mathrm{M} \mathrm{NaCl}$, and aliquots frozen at $-70^{\circ} \mathrm{C}$. For enrichment of plasma membranes, the $10,000 \mathrm{~g}$ pellet was rehomogenized in STE and centrifuged in a Percoll gradient as described (Nakamura et al. 1983). After extensive washing, the plasma membrane fractions were aliquoted and stored at $-70^{\circ} \mathrm{C}$. Total protein content was determined with the enhanced BCA assay (Pierce, Rockford IL).

\section{EGFR autophosphorylation}

Samples of freshly thawed microsomal membranes $(50 \mu \mathrm{g}$ protein/ were incubated for $1 \mathrm{hr}$ on ice with designated concentrations of murine EGF (GIBCO BRL) in $40 \mu$ l of $50 \mathrm{~mm}$ PIPES ( $\mathrm{pH}$ 7.0 ), $30 \mathrm{mM} \mathrm{MgCl}_{2}$. Autophosphorylation was initiated by the addition of $10 \mu \mathrm{l}$ of $\left[\gamma^{-32} \mathrm{P}\right] \mathrm{ATP}(0.5 \mu \mathrm{Ci} / \mathrm{ml})$ in $5 \mu \mathrm{M}$ ATP. After $1 \mathrm{~min}$ on ice (unless specified otherwise), reactions were stopped with $50 \mu \mathrm{l}$ of $2 \times$ SDS-PAGE sample buffer, and proteins resolved on $7 \%$ denaturing SDS-polyacrylamide gels. Gels were fixed in $10 \%$ isopropanol and $10 \%$ acetic acid and dried for autoradiography. Where indicated, dried gels were rehydrated, heated at $55^{\circ} \mathrm{C}$ for $2 \mathrm{hr}$ in $1 \mathrm{M} \mathrm{KOH}$ to preferentially remove serine/threonine phosphorylation, and fixed and dried for autoradiography. In some experiments, autophosphorylation was performed with solubilized membranes in the presence of $0.1 \%$ Triton X-100, after $1 \mathrm{hr}$ incubation at room temperature with 
ligand or antibody. In others, we observed that the level of either wild-type or wa-2 EGFR autophosphorylation was not significantly different when membranes were incubated in the presence of $200 \mu \mathrm{M}$ vanadate.

\section{Tyrosine kinase assay}

Aliquots $(100 \mu \mathrm{l})$ of freshly thawed liver microsomal membranes were solubilized on ice in $1 \%$ Triton X-100/10\% glycerol, diluted to $1 \mathrm{ml}$ with immunoprecipitation (IP) buffer [50 mM HEPES (pH 7.5), $0.15 \mathrm{~mm} \mathrm{NaCl}, 1 \mathrm{~mm}$ EDTA, 1\% Triton $\mathrm{X}-100,10 \%$ glycerol, $1 \mathrm{mM}$ PMSF, $20 \mu \mathrm{g} / \mathrm{ml}$ of leupeptin, 0.1 $\mathrm{TTU} / \mathrm{ml}$ of aprotinin] and incubated for $2 \mathrm{hr}$ on ice with either $10 \mu \mathrm{l}$ of preimmune rabbit serum or 1382 rabbit antiserum that recognizes the external domain of EGFR. Immune complexes were precipitated with $20 \mu \mathrm{l}$ of $50 \%$ (vol/vol) Staph A cells (Pansorbin, Calbiochem) for $2 \mathrm{hr}$ at $4^{\circ} \mathrm{C}$, washed once with IP buffer, and washed twice and resuspended with $2 \times$ tyrosine kinase buffer [100 mM HEPES (pH 7.6), $60 \mathrm{~mm} \mathrm{MgCl}_{2}, 4 \mathrm{~mm}$ $\left.\mathrm{MnCl}_{2}, 0.2 \% \mathrm{NP}-40,400 \mu \mathrm{M} \mathrm{Na} \mathrm{VO}_{4}\right)$. Immunoprecipitates (from $300 \mu \mathrm{g}$ of original membrane protein) were incubated for $15 \mathrm{~min}$ at $25^{\circ} \mathrm{C}$ with $2 \mathrm{mg} / \mathrm{ml}$ of poly-Glu acid or poly-(Glu/ $\mathrm{Na}, \mathrm{Tyr} ; 4: 1$ ) or poly-(Glu, Ala, Tyr; $6: 3: 1$ ) (Sigma) in $80 \mu \mathrm{l}$ of $1 \times$ tyrosine kinase buffer containing $0.5 \%$ Triton $\mathrm{X}-100$ and 5.0 $\mu \mathrm{Ci}\left[\gamma^{-32} \mathrm{P}\right] \mathrm{ATP}$ in $10 \mu \mathrm{MATP}$. Reactions were microcentrifuged for $1 \mathrm{~min}$ to pellet the immunoprecipitates, and $50 \mu$ l of supernatant spotted onto Whatman 3MM filter paper squares. The filter papers were washed for $30 \mathrm{~min}$ each in $10 \%$ trichloroacetic acid (TCA), $10 \mathrm{~mm}$ sodium pyrophosphate, and two changes of $5 \%$ TCA, dried overnight, and counted in liquid scintillation cocktail.

\section{In vivo phosphorylation}

Control $(+1-)$ and wavy-haired mutant $(-1-1$ pups (7-8 days old) of similar weight were injected subcutaneously in the neck with $20-30 \mu$ l of phosphate-buffered saline (PBS) or indicated amounts of EGF in PBS. Ten minutes later, mice were sacrificed and tissues harvested and homogenized as described previously (Donaldson and Cohen 1992). Protein concentrations in centrifuged tissue homogenates were determined with a Coomassie blue dye-binding assay (Bio-Rad). Equivalent amounts of protein were resolved by denaturing $7 \%$ SDS-PAGE, transferred to Immobilon-P (Millipore), and subjected to immunoblotting with rabbit anti-ERCT (raised against a glutathione- $S$-transferase protein containing the carboxy-terminal-most 100 amino acids of rat EGFR; 1:1000 dilution) or with monoclonal antibody to phosphotyrosine $(1: 10,000$ dilution of PY-20 coupled to horseradish peroxidase, ICN), followed by chemiluminescent detection (ECL, Amersham). Where indicated, neonatal tissue homogenates were immunoprecipitated with the EGFR antiserum and protein A-Sepharose (Pharmacia) prior to SDS-PAGE and immunoblotting.

\section{Nucleic acid analyses}

Total RNA was isolated and subjected to Northern analysis as described previously (Han et al. 1987). Two overlapping 2-kb cDNAs corresponding roughly to the extracellular and intracellular domains of the EGF receptor were generated by reverse transcription of $1 \mu \mathrm{g}$ total liver RNAs and subsequent PCR amplification (Luetteke et al. 1993). The first primer pair amplified from nucleotide position -149 to position $+1857,85 \mathrm{bp}$ upstream from the transmembrane domain: $5^{\prime}$-TACCGCCTCCCAGACAGACGA-3' (forward) and 5'-TAGGTGGCAGACATTATTGGCATC-3' (reverse). The second primer pair am- plified from position 1580 to position 3697,65 bp downstream of the stop codon: 5'-AGAATGTGAGCAGAGGCAGGGA-3' (forward) and 5'-CTGCCATGGCTTGGTCCTGGG-3' (reverse). PCR was performed for 30 cycles of $1 \mathrm{~min}$ each at $94^{\circ} \mathrm{C}$, $1 \mathrm{~min}$ at $60^{\circ} \mathrm{C}$, and $3 \mathrm{~min}$ at $72^{\circ} \mathrm{C}$. Products were resolved on $1 \%$ agarose gels, and the cDNAs isolated (GeneClean, Bio 101) and subcloned into the pCR II vector (TA cloning kit, Invitrogen). These mouse cDNAs were used as probes in the Northern and in situ hybridizations (Sandgren et al. 1993). The nucleic acid sequence of the cloned products was determined by the UNC$\mathrm{CH}$ Automated DNA Sequencing Facility using Applied Biosystems, Inc., instrumentation. Manual sequencing was performed with the Sequenase version 2.0 kit (U.S. Biochemical).

\section{Cell Transfections}

CHO cells were obtained from the American Tissue Culture Collection (ATCC) and grown in Dulbecco's minimal essential medium (DMEM) supplemented with nonessential amino acids and $10 \%$ fetal bovine serum (FBS). Cells in $60-\mathrm{mm}$ dishes at $50-80 \%$ confluency were transfected with $18 \mu$ l of lipofectamine (GIBCO/BRL) and $3 \mu \mathrm{g}$ of EGFR constructs as recommended by the manufacturer.

\section{Acknowledgments}

We thank Ruth Dy for technical advice, Tom Dawson and William Huckle for preparing EGFR antiserum, Mary Davis and Drew Hissong for assistance in preparing the manuscript and illustrations, respectively, and Leslie Petch and Eugene Berkowitz for computer analyses. We also thank William Huckle for his contribution of the rat EGFR cDNA clone and Stanley Cohen for helpful discussions. This work was supported by National Institutes of Health (NIH) grants CA-43793 (D.C.L.) and DK30002 (H.S.E.) and by the National Cancer Institute, Department of Health and Human Services under contract NO1-CO74101 with ABL. N.C.L. was the recipient of a postdoctoral fellowship from NIH.

\section{References}

Adamson, E.D. 1990. Developmental activities of the epidermal growth factor receptor. Curr. Topics Dev. Biol. 24: 1-29.

Avivi, A., I. Lax, A. Ullrich, J. Schlessinger, D. Givol, and B. Morse. 1991. Comparison of EGF receptor sequences as a guide to study the ligand binding site. Oncogene 6: 673-676.

Bargmann, C.I., M.-C. Hung, and R.A. Weinberg. 1986. The neu oncogene encodes an epidermal growth factor receptor-related protein. Nature 319: 226-230.

Barrandon, Y. and H. Green. 1987. Cell migration is essential for sustained growth of keratinocyte colonies: The roles of transforming growth factor- $\alpha$ and epidermal growth factor. Cell 50: 1131-1137.

Barrow, L.L., K. Simin, J.M. Jones, D.C. Lee, and M.H. Meisler. 1994. Conserved linkage of early growth response 4, annexin 4 , and transforming growth factor alpha on mouse chromosome 6. Genomics (in press).

Bennett, J. H. and G.A. Gresham. 1956. A gene for eyelids open at birth in the house mouse. Nature 178: 272-273.

Bertics, P.J., W. Weber, C. Cochet, and G.N. Gill. 1985. Regulation of the epidermal growth factor receptor by phosphorylation. J. Cell. Biochem. 29: 195-208.

Buday, L. and J. Downward. 1993. Epidermal growth factor regulates $\mathrm{p} 21^{\text {ras }}$ through the formation of a complex of receptor, Grb2 adapter protein, and Sos nucleotide exchange factor. 
Cell 73: 611-620.

Butler, L. and D.A. Robertson. 1953. A new eye abnormality in the house mouse. J. Hered. 44: 13-16.

Campos-Gonzalez, R. and J.R. Glenney. 1992. Tyrosine phosphorylation of mitogen-activated protein kinase in cells with tyrosine kinase-negative epidermal growth factor receptors. I. Biol. Chem. 267: 14535-14538.

Carpenter, G. 1992. Receptor tyrosine kinase substrates: src homology domains and signal transduction. FASEB I. 6: 32833289.

Carpenter, G. and M.I. Wahl. 1990. The epidermal growth factor family. In Handbook of experimental pharmacology (ed. M.B. Sporn and A.B. Roberts), pp. 69-171 Springer-Verlag, Berlin, Germany.

Chardin, P., J.H. Camonis, N.W. Gale, L.V. Aelst, J. Schlessinger, M.H. Wigler, and D. Bar-Sagi. 1993. Human sosl: A guanine nucleotide exchange factor for ras that binds to GRB2. Science 260: 1338-1343.

Chen, W.S., C.S. Lazar, M. Poenie, R.Y. Tsien, G.N. Gill, and M.G. Rosenfeld. 1987. Requirement for intrinsic protein tyrosine kinase in the immediate and late actions of the EGF receptor. Nature 328: 820-823.

Cheng, C., T. Tennenbaum, P.J. Dempsey, R.J. Coffey, S.H. Yuspa, and A.A. Dlugosz. 1993. Epidermal growth factor receptor ligands regulate keratin 8 expression in keratinocytes, and transforming growth factor $\alpha$ mediates the induction of keratin 8 by the v-ras ${ }^{\mathrm{Ha}}$ oncogene. Cell Growth Diff. 4: 317327.

Cohen, S. 1962. Isolation of a mouse submaxillary gland protein accelerating incisor eruption and eyelid opening in the newborn animal. J. Biol. Chem. 237: 1555-1562.

Crew, F.A. 1933. Waved: An autosomal recessive coat form character in the mouse. J. Genet. 27: 95-96.

Donaldson, R.W. and S. Cohen. 1992. Epidermal growth factor stimulates tyrosine phosphorylation in the neonatal mouse: Association of a $M_{\mathrm{r}} 55,000$ substrate with the receptor. Proc. Natl. Acad. Sci. 89: 8477-8481.

Egan, S.E., B.W. Giddings, M.W. Brooks, L. Buday, A.M. Sizeland, and R.A. Weinberg. 1993. Association of Sos Ras exchange protein with Grb2 is implicated in tyrosine kinase signal transduction and transformation. Nature 363: 45-51.

Fowler, K.J., G.B. Mann, and A.R. Dunn. 1993. Linkage of the murine transforming growth factor $\alpha$ gene with $I g k, L y-2$, and Fabp 1 on chromosome 6. Genomics 16: 782-784.

Freidenberg, G.R., H.H. Klein, M.P. Kladde, R. Cordera, and J.M. Olefsky. 1986. Regulation of epidermal growth factor receptor number and phosphorylation by fasting in rat liver. $J$. Biol. Chem. 261: 752-757.

Gale, N.W., S. Kaplan, E.J. Lowenstein, J. Schlessinger, and D. Bar-Sagi. 1993. Grb2 mediates the EGF-dependent activation of guanine nucleotide exchange on ras. Nature 363: 88-92.

Glenney, J.R. Jr., W.S. Chen, C.S. Lazar, G.M. Walton, L.M. Zokas, M.G. Rosenfeld, and G.N. Gill. 1988. Ligand-induced endocytosis of the EGF receptor is blocked by mutational inactivation and by microinjection of anti-phosphotyrosine antibodies. Cell 52: 675-684.

Green, M.R., D. Phil, and J.R. Couchman. 1984. Distribution of epidermal growth factor receptors in rat tissues during embryonic skin development, hair formation, and the adult hair growth cycle. I. Invest. Dermatol. 83: 118-123.

Han, V.K.M., E.S. Hunter III, R.M. Pratt, J.G. Zendegui, and D.C. Lee. 1987. Expression of rat transforming growth factor alpha mRNA during development occurs predominantly in the maternal decidua. Mol. Cell. Biol. 7: 2335-2343.

Hanks, S.K., A.M. Quinn, and T. Hunter. 1988. The protein kinase family: Conserved features and deduced phylogeny of the catalytic domains. Science 241: 42-52.

Hardy, M.H. 1992. The secret life of the hair follicle. Trends Genet. 8: 55-61.

Higashiyama, S., J.A. Abraham, J. Miller, J.C. Fiddes, and M. Klagsbrun. (1991). A heparin-binding growth factor secreted by macrophage-like cells that is related to EGF. Science 251: 936-939.

Honegger, A.M., T.J. Dull, S. Felder, E. Van Obberghen, F. Bellot, D. Szapary, A. Schmidt, A. Ullrich, and J. Schlessinger. 1987. Point mutation at the ATP binding site of EGF receptor abolishes protein-tyrosine kinase activity and alters cellular routing. Cell 51: 199-209.

Honegger, A., T.J. Dull, D. Szapary, A. Komoriya, R. Kris, A. Ullrich, and J. Schlessinger. 1988. Kinetic parameters of the protein tyrosine kinase activity of EGF-receptor mutants with individually altered autophosphorylation sites. $E M B O$ J. 7: 3053-3060.

Honegger, A.M., A. Schmidt, A. Ullrich, and J. Schlessinger. 1990. Separate endocytic pathways of kinase-defective and -active EGF receptor mutants expressed in same cells. $J$. Cell. Biol. 110: 1541-1548.

Keeler, C.E. 1935. A second rexoid coat character in the house mouse. I. Hered. 26: 189-191.

Kimura, H., W.H. Fischer, and D. Schubert. 1990. Structure, expression and function of a schwannoma-derived growth factor. Nature 348: 257-260.

King, L.E. Jr., R.E. Gates, C.M. Stoscheck, and L.B. Nanney. 1990. The EGF/TGF $\alpha$ receptor in skin. I. Invest. Dermatol. 94: 164S-170S.

Koch, C.A., D. Anderson, M.F. Moran, C. Ellis, and T. Pawson. 1991. SH2 and SH3 domains: Elements that control interactions of cytoplasmic signaling proteins. Science 252: 668674.

Kokai, Y., K. Dobashi, D.B. Weiner, J.N. Myers, P.C. Nowell, and M.I. Greene. 1988. Phosphorylation process induced by epidermal growth factor alters the oncogenic and cellular neu (NGL) gene products. Proc. Natl. Acad. Sci. 85: 53895393.

Kraus, M.H., W. Issing, T. Miki, N.C. Popescu, and S.A. Aaronson. 1989. Isolation and characterization of $E R B B 3$, a third member of the $E R B B$ /epidermal growth factor receptor family: Evidence for overexpression in a subset of human mammary tumors. Proc. Natl. Acad. Sci. 86: 9193-9197.

Li, N., A. Batzer, R. Daly, V. Yajnik, E. Skolnik, P. Chardin, D. Bar-Sagi, B. Margolis, and J. Schlessinger. 1993. Guaninenucleotide-releasing factor hSos1 binds to Grb2 and links receptor tyrosine kinases to Ras signalling. Nature 363: 8587.

Lowenstein, E.J., R.J. Daly, A.G. Batzer, W. Li, B. Margolis, R. Lammers, A. Ullrich, E.Y. Skolnik, D. Bar-Sagi, and J. Schlessinger. 1992. The SH2 and SH3 domain-containing protein GRB2 links receptor tyrosine kinases to ras signaling. Cell 70: 431-442.

Luetteke, N.C., T.H. Qiu, R.L. Peiffer, P. Oliver, O. Smithies, and D.C. Lee. 1993. TGF $\alpha$ deficiency results in hair follicle and eye abnormalities in targeted and waved-1 mice. Cell 73: 263-278.

Lyon, M.F. and A.G. Searle. 1989. Genetic variants and strains of the laboratory mouse, 2nd ed. Oxford University Press, Oxford, England.

McLaren, A. 1971. The microscopic appearance of waved-2 mouse hairs. Genet. Res. Camb. 17: 257-260.

McLaren, A. and P. Bowman. 1969. Mouse chimaeras derived from fusion of embryos differing by nine genetic factors. $\mathrm{Na}$ ture 224: 238-240.

Mann, G.B., K.J. Fowler, A. Gabriel, E.C. Nice, R.L. Williams, 
and A.R. Dunn. 1993. Mice with a null mutation of the TGF- $\alpha$ gene have abnormal skin architecture, wavy hair, and curly whiskers and often develop corneal inflammation. Cell 73: 249-261.

Margolis, B., F. Bellot, A.M. Honegger, A. Ullrich, J. Schlessinger, and A. Zilberstein. 1990. Tyrosine kinase activity is essential for the association of phospholipase C- $\gamma$ with the epidermal growth factor receptor. Mol. Cell. Biol. 10: 435441.

Marquardt, H., M.W. Hunkapiller, L.E. Hood, and G.J. Todaro. 1984. Rat transforming growth factor type 1: Structure and relation to epidermal growth factor. Science 223: 10791082.

Mayes, E.L.V. and M.D. Waterfield. 1984. Biosynthesis of the epidermal growth factor receptor in A431 cells. EMBO I. 3: $531-537$.

Moore, G.P.M., B.A. Panaretto, and D. Robertson. 1983. Epidermal growth factor delays the development of the epidermis and hair follicles of mice during growth of the first coat. Anat. Rec. 205: 47-55.

Nakamura, T., A. Tomomura, C. Noda, M. Shimoii, and A. Ichihara. 1983. Acquisition of a $\beta$-adrenergic response by adult rat hepatocytes during primary culture. I. Biol. Chem. 258: 9283-9289.

Nanney, L.B., R.E. Gates, G. Todderud, L.E. King Jr., and G. Carpenter. 1992. Altered distribution of phospholipase C- $\gamma \mathbf{l}$ in benign hyperproliferative epidermal diseases. Cell Growth Differ. 3: 233-239.

$\mathrm{Ng}, \mathrm{M}$. and M.L. Privalsky. 1986. Structural domains of the avian erythroblastosis virus $e r b B$ protein required for fibroblast transformation: dissection by in-frame insertional mutagenesis. J. Virol. 58: 542-553.

Pelicci, G., L. Lanfrancone, F. Grignani, J. McGlade, F. Cavallo, G. Forni, I. Nicoletti, F. Grignani, T. Pawson, and P.G. Pelicci. 1992. A novel transforming protein (SHC) with an $\mathrm{SH} 2$ domain is implicated in mitogenic signal transduction. Cell 70: 93-104.

Plowman, G.D., G.S. Whitney, M.G. Neubauer, J.M. Green, V.L. McDonald, G.J. Todaro, and M. Shoyab. 1990. Molecular cloning and expression of an additional epidermal growth factor receptor-related gene. Proc. Natl. Acad. Sci. 87: 49054909.

Plowman, G.D., J.-M. Culouscou, G.S. Whitney, J.M. Green, G.W. Carlton, L. Foy, M.G. Neubauer, and M. Shoyab. 1993. Ligand-specific activation of HER4/p180 ${ }^{\text {erbB4 }}$, a fourth member of the epidermal growth factor receptor family. Proc. Natl. Acad. Sci. 90: 1746-1750.

Prywes, R., E. Livneh, A. Ullrich, and J. Schlessinger. 1986. Mutations in the cytoplasmic domain of EGF receptor affect EGF binding and receptor internalization. EMBO I. 5: 21792190.

Rotin, D., A.M. Honegger, B.L. Margolis, A. Ullrich, and J. Schlessinger. 1992. Presence of SH2 domains of phospholipase $\mathrm{C} \gamma$ enhances substrate phosphorylation by increasing the affinity toward the epidermal growth factor receptor. $J$. Biol. Chem. 267: 9678-9683.

Rozakis-Adcock, M., J. McGlade, G. Mbamalu, G. Pelicci, R. Daly, W. Li, A. Batzer, S. Thomas, J. Bruggs, P.G. Pelicci, J. Schlessinger, and T. Pawson. 1992. Association of the Shc and $\mathrm{Grb} 2 / \mathrm{Sem} 5 \mathrm{SH} 2$-containing proteins is implicated in activation of the ras pathway by tyrosine kinases. Nature 360: 689-692.

Rozakis-Adcock, M., R. Fernley, J. Wade, T. Pawson, and D. Bowtell. 1993. The SH2 and SH3 domains of mammalian Grb2 couple the EGF receptor to the ras activator mSosl. Nature 363: 83-84.
Rubin, R.A. and H.S. Earp. 1983. Dimethyl sulfoxide stimulates tyrosine residue phosphorylation of rat liver epidermal growth factor receptor. Science 219: 60-63.

Ruff-Jamison, S., J. McGlade, T. Pawson, K. Chen, and S. Cohen. 1993. Epidermal growth factor stimulates the tyrosine phosphorylation of SHC in the mouse. J. Biol. Chem. 268: 7610 7612.

Russell, E.S. 1979. Hereditary anemias of the mouse: A review for geneticists. Adv. Genet. 20: 357-459.

Sandgren, E.P., N.C. Luetteke, T.H. Qiu, R.D. Palmiter, R.L. Brinster, and D.C. Lee. 1993. TGF- $\alpha$ dramatically enhances oncogene-induced cardinogenesis in pancreas and liver of transgenic mice. Mol. Cell. Biol. 13: 320-330.

Sasada, R., Y. Ono, Y. Taniyama, Y. Shing, J. Folkman, and K. Igarashi. 1993. Cloning and expression of cDNA encoding human betacellulin, a new member of the EGF family. Biochem. Biophys. Res. Comm. 190: 1173-1179.

Schlessinger, J. 1988. Signal transduction by allosteric receptor oligomerization. Trends Biochem. Sci. 13: 443-447.

Schreiber, A.B., T.A. Libermann, I. Lax, Y. Yarden, and J. Schlessinger. 1983. Biological role of epidermal growth factor receptor clustering. I. Biol. Chem. 258: 846-853.

Segatto, O., F. Lonardo, D. Wexler, F. Fazioli, J.H. Pierce, D.P. Bottaro, M.F. White, and P.P. Di Fiore. 1991. The juxtamembrane regions of the epidermal growth factor receptor and gp185 ${ }^{\text {erbB-2 }}$ determine the specificity of signal transduction. Mol. Cell. Biol. 11: 3191-3202.

Selva, E., D.L. Raden, and R.J. Davis. 1993. Mitogen-activated protein kinase stimulation by a tyrosine kinase-negative epidermal growth factor receptor. J. Biol. Chem. 268: 22502254.

Shing, Y., G. Christofori, D. Hanahan, Y. Ono, R. Sasada, K. Igarashi, and J. Folkman. 1993. Betacellulin: A mitogen from pancreatic $\beta$ cell tumors. Science 259: 1604-1607.

Shoyab, M., G.D. Plowman, V.L. McDonald, J.G. Bradley, and G.J. Todaro. 1989. Structure and function of human amphiregulin: A member of the epidermal growth factor family. Science 243: 1074-1076.

Shu, H.K., R.J. Pelley, and H.J. Kung. 1990. Tissue-specific transformation by epidermal growth factor receptor: A single point mutation within the ATP-binding pocket of the $e r b B$ product increases its intrinsic kinase activity and activates its sarcomagenic potential. Proc. Natl. Acad. Sci. 87: 9103-9107.

Slieker, L.J. and M.D. Lane. 1985. Post-translational processing of the epidermal growth factor receptor. J. Biol. Chem. 260: $687-690$.

Soderquist, A.M. and G. Carpenter. 1984. Glycosylation of the epidermal growth factor receptor in A-431 cells. $J$. Biol. Chem. 259: 12586-12594.

Straile, W.E. 1962. Possible functions of the external root sheath during growth of the hair follicle. J. Exp. Zool. 150: 207-224.

Tam, J.P. 1985. Physiological effects of transforming growth factor in newborn mouse. Science 229: 673-675.

Trigg, M.J. 1972. Hair growth in mouse mutants affecting coat texture. J. Zool. 168: 165-198.

Ullrich, A. and J. Schlessinger. 1990. Signal transduction by receptors with tyrosine kinase activity. Cell 61: 203-212.

Ullrich, A., L. Coussens, J.S. Hayflick, T.J. Dull, A. Gray, A.W. Tam, J. Lee, Y. Yarden, T.A. Libermann, J. Schlessinger, J. Downward, E.L.V. Mayes, N. Whittle, M.D. Waterfield, and P.H. Seeburg. 1984. Human epidermal growth factor receptor cDNA sequence and aberrant expression of the amplified gene in A431 epidermoid carcinoma cells. Nature 309: 418425.

Vassar, R. and E. Fuchs. 1991. Transgenic mice provide new 
insights into the role of TGF- $\alpha$ during epidermal development and differentiation. Genes \& Dev. 5: 714-727.

Wiley, L.M., J.-X. Wu, I. Harari, and E.D. Adamson. 1992. Epidermal growth factor receptor mRNA and protein increase after the four-cell preimplantation stage in murine development. Dev. Biol. 149: 247-260.

Wittinghofer, A. and E.F. Pai. 1991. The structure of ras protein: A model for a universal molecular switch. Trends Biol. Sci. 16: 382-387.

Yarden, Y. and J. Schlessinger, J. 1987. Epidermal growth factor induces rapid, reversible aggregation of the purified epidermal growth factor receptor. Biochemistry 26: 1443-1451.

Zick, Y., G. Grunberger, R.W. Rees-Jones, and R.J. Comi. 1985. Use of tyrosine-containing polymers to characterize the substrate specificity of insulin and other hormone-stimulated tyrosine kinases. Eur. J. Biochem. 148: 177-182. 


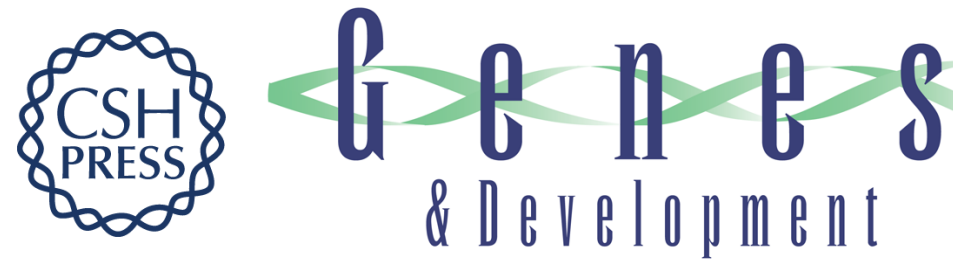

\section{The mouse waved-2 phenotype results from a point mutation in the EGF receptor tyrosine kinase.}

N C Luetteke, H K Phillips, T H Qiu, et al.

Genes Dev. 1994, 8:

Access the most recent version at doi:10.1101/gad.8.4.399

References This article cites 79 articles, 34 of which can be accessed free at:

http://genesdev.cshlp.org/content/8/4/399.full.html\#ref-list-1

License

Email Alerting

Service

Receive free email alerts when new articles cite this article - sign up in the box at the top right corner of the article or click here.

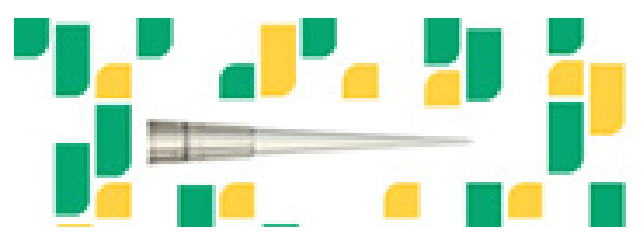

Focused on your science. 